\title{
Rubinstein-Taybi syndrome with humoral and cellular defects: a case report
}

\author{
Anthony Villella, Dalia Bialostocky, Eli Lori, Howard Meyerson, Robert W Hostoffer
}

\begin{abstract}
The first association of Rubinstien-Taybi syndrome with immunodeficiency and the successful prevention of infection with intravenous IgG is reported in a 4 year old boy. This case suggests that immunodeficiency maybe a prominent feature of this syndrome and may predispose these patients to recurrent infections.

(Arch Dis Child 2000;83:360-361)
\end{abstract}

Keywords: Rubinstein-Taybi syndrome; immunodeficiency

The first description of Rubinstein-Taybi syndrome (broad thumb-hallux syndrome) was reported in 1963 and was subsequently followed by others. ${ }^{1}$ The syndrome's major characteristics are short stature, mental retardation, broad thumbs and first toes, cardiac abnormalities, feeding difficulties, and recurrent upper respiratory tract infections. ${ }^{1-3}$ These infections have been thought to be secondary to microaspiration and gastro-oesophageal reflux although few studies have attempted to completely define the immunological status of these patients. ${ }^{2}$ We report the first association of Rubinstien-Taybi syndrome with immunodeficiency and the successful prevention of infection with intravenous IgG. This case suggests that immunodeficiency may be a prominent feature of this syndrome and may predispose these patients to recurrent infections.

\section{Department of}

Pediatrics, Rainbow

Babies and Children's

Hospital, Cleveland,

Ohio, USA

A Villella

E Lori

Hospital infantil de Mexico "Federico

Gomez", Mexico City, Mexico

D Bialostocky

Department of

Pathology, University

Hospital, Cleveland,

Ohio, USA

$\mathrm{H}$ Meyerson

1611 South Green

Road, South Euclid, Ohio 44121, USA

R W Hostoffer

Correspondence to:

Dr Hostoffer

email:

k.hostoffer@worldnet.att.net

Accepted 24 May 2000

\section{Case report}

JC is a 4 year old white male with previously diagnosed Rubinstein-Taybi syndrome. He was a product of a caesarean section with a birth weight of 4.5 pounds. He was diagnosed with an atrial septal defect, a bicuspid aortic valve, fused kidney, gastro-oesophageal reflux (repaired with a Nissen fundiplication and G tube), and developmental delay. $\mathrm{He}$ has been restricted to a wheelchair and has made minor attempts with ambulating only recently at age 8. He remains non-verbal with only occasional visual response to verbal stimuli. $\mathrm{He}$ has the characteristic broad thumbs and thick fingers described with the Rubinstein-Taybi syndrome. During the first few years of life he experienced recurrent ear infections with purulent discharge from the canals that were treated with oral antibiotics. Several episodes of high spiking fevers were also noted and in most cases required full septic evaluations because of apparent toxicity. Cultures of blood, cerebrospinal fluid, and urine invariably were negative.
In addition, multiple episodes of purulent rhinitis with fever were often documented.

After 1 year of age, three pneumonias were documented by radiographs and subsequently treated with oral antibiotics. Because of the excessive use of antibiotics the patient developed several episodes of Clostridium difficile enteritis. He acquired bilateral hearing loss as a result of the recurrent ear infections. He was seen in the immunology clinic at 2 years of age for the evaluation of these recurrent infections. His subsequent laboratory data showed a mild leucopenia with a subsequent lymphopenia. Further evaluation of the lymphocyte compartment showed decreased CD3, CD 4, CD8+ T, and CD19+ B cells (table 1). Mitogen and antigen stimulation was normal except for a mildly diminished response to concanavalin A (table 2). These levels were similar on many determinations. Serum immunoglobulins showed a depressed IgM and an increased IgA. The IgG subclasses were quantitatively normal but the patient failed to respond to Pneumovax (table 1). Antibody responses to tetanus and diphtheria were normal. CH50, pit count, adenosine deaminase, and purine nucleoside phosphorylase levels were all normal. HIV culture and serology were negative. The patient was started on intravenous IgG at a dose of 0.4 $\mathrm{g} / \mathrm{kg}$ monthly. Because of the low numbers of CD4+T cells the patients was started on Pneumocystis carinii prophylaxis with trimethoprimsulphamethoxazole. He responded favourably to therapy with fewer and less severe infections. In addition his tympanometry improved although no direct measurement of hearing
Table 1 Immunological results

\begin{tabular}{lll}
\hline CD3 & $0.4 \times 10^{9} / 1$ & $1.8-3.0 \times 10^{9} / 1$ \\
CD4 & $0.23 \times 10^{9} / 1$ & $1.0-1.8 \times 10^{9} / 1$ \\
CD8 & $0.16 \times 10^{9} / 1$ & $0.8-1.5 \times 10^{9} / 1$ \\
CD19 & $0.09 \times 10^{9} / 1$ & $0.7-1.3 \times 10^{9} / 1$ \\
IgG & $71.0 \mathrm{~g} / 1$ & $33.5-97.5 \mathrm{~g} / 1$ \\
IgA & $24.7 \mathrm{~g} / 1$ & $1.7-7.0 \mathrm{~g} / 1$ \\
IgM & $1.4 \mathrm{~g} / 1$ & $2.2-12.4 \mathrm{~g} / 1$ \\
IgG1 & $52.8 \mathrm{~g} / 1$ & $3.13-96.1 \mathrm{~g} / 1$ \\
IgG2 & $6.6 \mathrm{~g} / 1$ & $6.5-4.56 \mathrm{~g} / 1$ \\
IgG3 & $5.6 \mathrm{~g} / 1$ & $1.1-12.5 \mathrm{~g} / 1$ \\
IgG4 & $1.4 \mathrm{~g} / 1$ & $0.1-7.0 \mathrm{~g} / 1$ \\
Pneumococcal serotypes & Pretitres & Post-titres \\
(>1.8 $\mu \mathrm{g} / \mathrm{ml})$ & & \\
Type 1 & $<0.3 \mu \mathrm{g} / \mathrm{ml}$ & $0.4 \mu \mathrm{g} / \mathrm{ml}$ \\
Type 3 & $<0.3 \mu \mathrm{g} / \mathrm{ml}$ & $0.6 \mu \mathrm{g} / \mathrm{ml}$ \\
Type 4 & $<0.3 \mu \mathrm{g} / \mathrm{ml}$ & $0.6 \mu \mathrm{g} / \mathrm{ml}$ \\
Type 6/26 & $<0.3 \mu \mathrm{g} / \mathrm{ml}$ & $0.6 \mu \mathrm{g} / \mathrm{ml}$ \\
Type 8 & $<0.3 \mu \mathrm{g} / \mathrm{ml}$ & $0.6 \mu \mathrm{g} / \mathrm{ml}$ \\
Type 9 & $<0.3 \mu \mathrm{g} / \mathrm{ml}$ & $0.6 \mu \mathrm{g} / \mathrm{ml}$ \\
Type 12 & $<0.3 \mu \mathrm{g} / \mathrm{ml}$ & $0.6 \mu \mathrm{g} / \mathrm{ml}$ \\
Type 14 & $<0.3 \mu \mathrm{g} / \mathrm{ml}$ & $0.6 \mu \mathrm{g} / \mathrm{ml}$ \\
Type 19 & $<0.3 \mu \mathrm{g} / \mathrm{ml}$ & $0.6 \mu \mathrm{g} / \mathrm{ml}$ \\
Type 23 & $<0.3 \mu \mathrm{g} / \mathrm{ml}$ & $0.6 \mu \mathrm{g} / \mathrm{ml}$ \\
Type 51 & $<0.3 \mu \mathrm{g} / \mathrm{ml}$ & $0.6 \mu \mathrm{g} / \mathrm{ml}$ \\
Type 56 & $<0.3 \mu \mathrm{g} / \mathrm{ml}$ & $0.6 \mu \mathrm{g} / \mathrm{ml}$ \\
Tetanus & $2.20 \mathrm{IU} / \mathrm{ml}$ & $>0.1 \mathrm{IU} / \mathrm{ml}$ \\
Diphtheria & $0.79 \mathrm{IU} / \mathrm{ml}$ & $>0.1 \mathrm{IU} / \mathrm{ml}$ \\
\hline
\end{tabular}


Table 2 In vitro $T$ cell proliferation results

\begin{tabular}{lll}
\hline Mitogen & Patient & Control \\
\hline Phytohaemagglutinin & 56137 & $30000-190000 \mathrm{cpm}$ \\
Concanavalin A & 27866 & $40000-155000$ \\
Background & 214 & $120-1000$ \\
Antigen & & \\
Candida & & \\
$\quad 1 / 10$ & 8755 & $9650 \mathrm{cpm}$ \\
$1 / 20$ & 6988 & 4650 \\
$1 / 40$ & 2455 & 2342 \\
$1 / 80$ & 1862 & 1567 \\
Background & 110 & 132 \\
\hline
\end{tabular}

has been performed. We have since followed this patient for several months without significant change in his immunological status.

\section{Discussion}

Rubinstein-Taybi syndrome was initially defined as a complex of clinical observations, which include mental retardation, broad thumbs and first great toe, short stature, and characteristic facial features. ${ }^{1}$ In addition, several reports noted that $52-78 \%$ of these patients develop recurrent respiratory tract infections. ${ }^{1-3}$ The infections frequently involved the upper respiratory tract and had been assumed to be secondary to microaspiration as a result of gastro-oesophageal reflux. ${ }^{2}$

Despite this syndrome's strong association with recurrent infection, there have been few reports describing immunological deficiencies with this syndrome. Rivas et al showed a defect of polymorphonuclear phagocytosis using a latex particle assay. In this same patient, there were decreased $\mathrm{T}$ cell number using rosette formation, delayed hypersensitivity to multiple antigens, and normal serum immunoglobulins. ${ }^{4}$ Kimura et al showed decreased thymic tissue at autopsy in one patient with Rubinstein-Taybi syndrome. Pre-autopsy, peripheral blood $\mathrm{T}$ cells were normal. $\mathrm{He}$ also noted that serum IgG levels were transiently diminished and serum IgA was low. ${ }^{5}$ Our patient similarly had low $\mathrm{T}$ cell number as well as mildly diminished $\mathrm{T}$ cell proliferation to concanavalin A. In addition our patient also had defects of both B cell number and antibody formation to polysaccharide antigens.

The association of an antipolysaccharide antibody deficiency with a $\mathrm{T}$ cell defect has been found in other syndromes. Rijkers et al reported that patients with DiGeorge syndrome may have antipolysaccharide antibody deficiency combined with their $\mathrm{T}$ cell defect. ${ }^{6}$ Additionally, patients with Wiskott-Aldrich syndrome also lack antibody responses to polysaccharide antigens such as isohaemagglutinins. ${ }^{78}$ These observations may seem to go against the traditional concept that antibody formation to polysaccharides are $\mathrm{T}$ cell independent, but the effects of $\mathrm{T}$ cell cytokines such as interleukin 4 have been shown to influence $B$ cell maturation and/or activation. This process may promote the antibody response to such antigens. ${ }^{9}$ Abnormalities of such $\mathrm{T}$ and $\mathrm{B}$ cell interactions may be responsible for the defect found in our patient.

Autoimmune manifestations have indeed been reported with $\mathrm{T}$ cell dysregulation. Depiero et al described two patients with velocardiofacial syndrome and recurrent immune cytopenias. ${ }^{10}$ Cases such as these strengthen the argument that clinical autoimmune disease, as well as poor immune function, is a consequence of immune dysregulation, although we have had no clinical evidence of autoimmune manifestations in this patient.

The propensity for recurrent infections and the findings of both $\mathrm{T}$ and $\mathrm{B}$ cell defects in our patient and those described in the literature suggest that an immunodeficiency may be a feature of Rubinstein-Taybi syndrome. Early diagnosis of this immunological deficit and institution of intravenous IgG and/or Pneumocystis carinii prophylaxis when appropriate may prevent end organ damage (hearing loss) and may improve the quality of life of these patients. Further studies should be performed in this group of patients in order to determine the exact frequency and nature of the immunological deficits.

1 Rubinstein JH, Taybi H. Broad thumbs and toes and facial abnormalities. Am $\mathcal{F}$ Dis Child 1963;105:588-607.

2 Rubinstein JH. Broad thumb-hallux (Rubinstein-Taybi) syndrome. Am f Med Genet 1990;6(suppl):3-16.

3 Stevens CA, Carey JC, Balckburn BL. Rubinstein-Taybi syndrome: a natural history study. $\mathrm{Am}$ f Med Genet 1990;6(suppl):30-7.

4 Rivas F, Fragoso R, Ramos-Zepeda R, et al. Deficient cell immunity and mild intermittent hyperaminoacidemia in a patient with the Rubinstein-Taybi syndrome. Acta Paediatr patient with the Rubin
Scand 1980;69:123-6.

5 Kimura H, Ito Y, Koda Y, Hase Y. Rubinstein-Taybi syndrome with thymic hypoplasia. Am $f$ Med Genet 1993;46:293-6

6 Rijker GT, Sanders LAM, Zegers BJM. Anticapsular polysaccharide antibody deficiency states. Immunodeficiency 1993;5:1-21.

7 Ming JE, Steim ER, Graham JM. Immunodeficiency as a component of recognizable syndromes. Am $\mathcal{f}$ Genet 1996;66:378-98.

8 Blaese RM, Strober W, Brown RS, Waldman TA. The Wiskott-Aldrich syndrome: a disorder with a possible defect in antigen processing or recognition. Lancet 1968;i: 1056-61.

9 Defrance T, Vabervliet B, Durand I, Banchereau J. Human interleukin 4 down regulates the surface expression of CD 5
on normal and leukemic B cells. Eur f Immunol on normal an

10 Depeiro A, Lourie E, Berman B, Robin N, Zinn A, Hostoffer R. Recurrent immune cytopenias in two patients with DiGeorge/velocardiofacial syndrome. $\mathcal{F}$ Pediatr 1997;131: $484-6$. 